\title{
DIGITAL MODELS OF INTERACTION DURING THE APPLICATION OF MECHANISMS FOR APPEALING THE SERVICE ACTIVITIES OF PUBLIC AUTHORITIES
}

\author{
Igor Pechenkin \\ Postgraduate Student at the Department of Information Policy and Digital Technologies, \\ National Academy of Public Administration under the President of Ukraine \\ e-mail: proky@ukr.net, orcid.org/0000-0002-64097695
}

\section{Mirosława Skalik}

Professor, Ph.D., Polonia University in Czestochowa, Interdisciplinary Faculty, Poland e-mail:mskalik@ap.edu.pl,orcid.org/0000-0002-6259-4794

\section{Summary}

In order to achieve high results in building a competitive economy and a responsible civil society, it is important to pay attention to the development of control systems over the adoption and implementation of management decisions. At present, such activities need to be modernized towards the digital transformation of public administration using the capabilities of information and communication technologies in accordance with international standards and international legal acts, most of which have been ratified by Ukraine. To do this, the only criterion of efficiency should be the actual result obtained from the service activities of public authorities, which should be transparent and competitive. It is necessary to develop models of digital interaction taking into account international experience. There is an urgent need in Ukraine to inspect obsolete norms and create on this basis effective models of digital interaction between the government and the citizen in the field of mechanisms for appealing against the service activities of public authorities.

The article describes the models of digital interaction in the application of mechanisms for appealing the provision of services by public authorities, identifies the main examples of successful application in practice of European countries. It is established that the influence on the provision of services by a citizen is mostly formal and declarative. The legal framework in this area must be modern and in line with international standards ratified by Ukraine.

Keywords: service activity, digital interaction, public authorities, appeal mechanisms, public administration, digital transformation.

DOI: https://doi.org/10.23856/4525

\section{Introduction}

Ensuring the state's mass introduction of information and communication technologies with the simultaneous digital transformation of public administration is considered in most countries as one of the national priorities. The existing digital divide causes countries to lag behind in the growth rate of goods and services, which automatically causes a lag in economic development, and the sustainable development of digitalization, on the contrary, improves the quality of life and competitiveness of the country in the international arena.

The SARS-CoV-2 virus pandemic has caused a global crisis and changed the order of life. The public and private sectors face the problem of providing access to all business processes and services. The unpredictable situation demonstrated the different level of digital 
inequality in the world to the readiness and ability to withstand emergencies in the provision of public services to the population.

Therefore, it is necessary to build a modern service-oriented policy of the state in relations with the citizen, because the person is his main value, and respect for human rights - the main purpose of public authorities. Governments should create and develop a legal framework, promote the scientific and technical implementation of the digitization of public authority instruments in accordance with the best European rights practices set out in the EU Charter of Fundamental Rights (1.EU. Charter). The need to reorganize interstate relations in this area between our countries is obvious. The initiative to create joint unifying platforms for digital data and registers of services of public authorities in the form of the system of electronic interaction of state electronic information resources "Trembita" created in Ukraine will promote the development of legal relations and the economy.

Ukrainian specialists in innovation in the field of information and communication technologies have shown themselves to the best of their ability and are desirable employees in the development of digital interaction services in all countries of the world. However, due to the above circumstances, the patriotic intentions of many of them to implement and assist their country in this area in the development and implementation of tools for digital transformation of public administration, communication between government and citizens remain relevant. Such a transformation is already taking place and is being carried out using digital technologies. Openness, transparency, government accountability and participation in governance are the basis for good governance, and technology ensures the accessibility and simplicity of these processes.

The state must ensure the effective implementation of international legislation adopted and ratified by it in the field of development of digital interaction in public administration, including for the development of mechanisms for appealing service activities. Civilizational progress and the growth of economic competition for resources push for the need for rapid development of digital interaction models. A clear example of the collapse of management decisions against the background of a global pandemic has exacerbated the need for such a need.

\section{International legal priorities for the development of digital interaction, including the use of mechanisms for complaining about the service activities of public authorities}

Sensitivity and danger to society have been demonstrated by a worldwide pandemic of the SARS-CoV-2 virus, which has claimed millions of lives worldwide. Mankind has been unprepared to accept global threats and has shown a level of readiness for a general mobilization of efforts to overcome negative phenomena.

One of the elements of opportunities for rapid and effective mobilization of efforts is efficiency in making and applying mechanisms for appealing management decisions. This should be facilitated by ensuring an appropriate level of digital interaction in the provision and receipt of services provided by the state to the citizen through public authorities.

In crisis situations, both the public and private sectors have faced the acute problem of providing access to all business processes, as well as obtaining and appealing for services remotely online. That is why the issue of digital transformation of public administration has become no longer a dogma, but an existing necessity.

Ensuring by the world's competitive economies the introduction of information and communication (digital) technologies (hereinafter ICT) as elements of digitalization of 
society is considered as one of the strategic tasks and national priorities. In the absence of such support, a digital divide is created, which causes the country to lag behind in the growth rate of goods and services produced through ICT. This automatically causes the country's economy to lag behind in economic development. At the same time, the sustainable development of the digital transformation of public administration, on the contrary, provides an increase in the country's competitiveness in the international arena, which automatically increases the quality of life.

The need for such development has become the basis for the development and adoption of countries with strong economies strategies for digital transformation in their countries. Among such countries that have already implemented the above strategy are: Belgium (5), Denmark (6), Germany (7), Singapore (8), the United States (9), Switzerland (10), Sweden (11).

In 2016, at the initiative of the Government of Ukraine and the non-governmental expert community, the Digital Agenda of Ukraine project "Digital Agenda 2020" was developed and adopted, which outlines the basic principles of digitalization of Ukraine in seventeen sections. Currently, in the expert environment, analysts of the independent analytical center "Ukrainian Institute of the Future" are creating a program document: "Ukraine 2030e - a country with a developed digital economy" with the development of direction for digitalization of public administration, which is presented in section 6.6.2. "The role of the state in achieving KRI" (4. Ukraine 2030).

It is obvious that in order to achieve its strategic goals, Ukraine needs to accelerate the development of digital transformations on the example of already implemented strategies and must ensure the normative consolidation of the experience of EU countries. Components of digital transformation can be: data registers; elements of digital transformation of both individual businesses and entire sectors of the economy and management; elements of the sharing economy; virtualization of physical infrastructure IT-systems; Artificial Intelligence; digital platforms.

In view of the global changes in the world in 2020, the Secretary-General of the United Nations (hereinafter UN) Antonio Guterres stressed the need for member states and others to "start a decade of work and action for the benefit of people and the planet" and presented a UN study: Digital government. Decade of Action for Sustainable Development (2. Research. United Nations. 2020).

According to the Department of Public Institutions and Digital Government of the UN Department of Economic and Social Affairs (3. EGDI Index. 2020), Ukraine in 2020 ranks 69th out of 193 countries in the e-Government Development Index (EGDI). It should be noted that since its inception in 2001, this Index has become an indispensable tool for ranking, mapping and changing development for digital governments, as well as policymakers, analysts engaged in comparative analysis and current research in the field of digital government. EGDI - is an index based on the average values of three other indices: one third of the data from the Telecommunications Infrastructure Index (TII), one third from the Human Capital Index (HCI), one third from the Online Services Index (OSI), and the latter collected on the basis data collected from the Independent Online Service Survey (OSQ) conducted by UNDESA, which assesses the national online presence of all 193 UN member states, supplemented by a Member State Survey (MSQ). The review also includes the Electronic Participation Index (EPI).

In pursuance of the above-mentioned UN initiative, on March 9, 2021, the European Commission in Brussels adopted a new Strategy for the Digital Transformation of Europe until 2030 and ways to achieve them "European Digital Decade" (4. EU Strategy). The European 
Commission proposes to introduce a digital compass for Europe to realize the EU's digital ambitions by 2030 within specific deadlines in four areas: citizens' digital skills; secure, productive and sustainable digital infrastructures; digital business transformation; digitization of public services.

The above indicates the urgent need to develop digital interaction in the adoption and implementation of decisions of public authorities and transparent access to such information to all online.

Today, the pandemic has intensified the role of digital interaction in government, both in the traditional provision of digital services and in new innovative crisis management efforts. Such crises have brought to the fore numerous problems and numerous forms of the digital divide, especially among the poorest sections of the population and the most vulnerable groups. While the pandemic has intensified the role of e-government, both in the traditional provision of digital services and in new innovative efforts to manage the crisis, it has also brought to the fore the many forms of the digital divide, especially among the poorest. and the most vulnerable groups. a tool for mapping and measuring development for digital ministers, policymakers and analysts involved in benchmarking and current e-government research. The launch of this review also takes place at an unprecedented time in the COVID-19 pandemic. While the pandemic has intensified the role of e-government, both in the traditional provision of digital services and in new innovative efforts to manage the crisis, it has also brought to the fore the many forms of the digital divide, especially among the poorest. and the most vulnerable groups.

\section{Classification of digital interaction models using mechanisms for appealing the service activities of public authorities}

Secure digital data exchange is one of the key components of the digital transformation of public administration. The practice of European experience in this area allows us to conclude that there are four basic approaches to the implementation of a secure experience of digital data exchange.

Such models can be called and characterized - centralized, decentralized, transitional and free models.

The centralized model is characterized by access to a single centralized IT system, to which digital data systems of certain public authorities are connected and serviced, which are the owners of basic registers and developed common access interfaces for all users in advance according to common requirements and formats. Access to such information and registers is possible for all other authorities that are connected to the centralized system. The authorities are connected to such a system by concluding pre-standardized standard agreements on digital interaction, which are carried out in order to use certain registers, which should be placed on a single digital platform with interoperable tools for its use according to uniform international norms.

At the same time, the central IT-system provides unified verification, routing, as well as ensures the delivery of messages and the appropriate level of logging of all actions. The system administrator provides centralized maintenance of the register of access services, access matrices, agreements on information interaction, maintenance of uniform semantic classifiers.

The decentralized model differs from the centralized architecture of the IT system, which provides automated data exchange between information systems of public authorities. The functions of logging, verification and routing of messages between information systems are transmitted through the capabilities of unique software for the parties, which is integrated in 
advance and provides data exchange of specific digital systems. That is, the difference is in the use of specialized software between the parties.

When using the transitional model, a comprehensive request for information is made responsibly to a specific scenario - the provision of appropriate administrative services, a defined set of access services of the central IT-system. It collects the necessary information from the access services of the basic registers of the authorities-supplier of information and generates a comprehensive response of the authority-customer of information. At the same time, the central IT-system implements the automation of business processes in accordance with specific scenarios for the implementation of government powers, which makes it possible to obtain information from several registers.

The free model involves the exchange of information by government systems through the use of open formats, protocols and regulations. This model assumes that each authority that introduces digital data exchange receives its own special software. This allows you to use the same functions for routing, identification, saving the entire history of data exchange, receiving and generating requests, processing and sending responses.

When considering approaches to legal regulation when using different models of digital interaction when using mechanisms to challenge the service activities of public authorities, it is necessary to take into account certain features. They arose as a result of different approaches in the history of legal regulation of countries, legal traditions, as well as political and economic traditions and differences between states. The main factors that determined the features of digital government legislation were the geography of the region to which the state belongs, taking into account certain geopolitical aspects. According to such criteria, the world distinguishes: Continental European model, Anglo-American model, Asian model.

In addition to the above, it is necessary to draw attention to the digital model of interaction for blockchain solutions, which has three levels of interoperability, namely: the level of agreements, technical level and level of infrastructure.

In more detail, the Ukrainian scientist Osmak A.S. researched the issue of detailed characteristics of blockchain systems and components of the concept of interoperability in his scientific works. Thus, he notes that the level of agreements involves the exchange of data between blockchain systems, in which the management models that govern such systems must be comparable in a clearly defined legal framework and agreements.

The components of the transaction level are:

a management system that ensures the reliability of participants and aims to develop and agree with different blockchain systems a common management model, where only qualified participants can provide information on a common platform, as they act on behalf of the whole system;

standardization of data is the exchange of validated data between participants in systems, which, to ensure uniformity of their interpretation by all participants in such exchange must comply with a standardized form;

the legal framework should determine the legal aspects of intersystem interoperability and the levels of responsibility of each of the participants in the blockchain system, ie: which jurisdiction is used in disputes, who controls the information and is responsible for its content, security and integrity.

The technical level assumes that for the interoperability of blockchain systems, it is necessary to consider whether these systems are technically compatible and whether the compatibility requirements are met. 
Infrastructure layer is a set of components that provides blockchain platform services, which include: computational methods, storage, network type and virtualization. Although interoperability is generally a compatible infrastructure, it is often complicated by certain components offered by cloud providers.

\section{Conclusion}

1. Digitalization of public administration - service activities of public authorities, introduction of common standards for storage and use of information, unification of databases of public authorities on single information platforms, interoperability of these systems, providing conditions for wide access to them, and is a recognized mechanism of economic growth due to the ability of technology to positively affect the efficiency, effectiveness, cost and quality of economic, social and personal activities. This term is quite new and not always clear to specialists in public administration and administration, but it is important for modern strategic planning and public administration reform in Ukraine.

2. Ensuring rapid use of information, openness and transparency of data will contribute to the development of the economy according to international standards Industry 4.0 - Strategy for the implementation of cyberphysical systems in the production and service of human needs, invented in 2011 in Germany - is a coordinated state initiative to mobilize all national resources in order to accelerate technological change and maintain German leadership in global competition, reform public administration, open and transparent decision-making and implementation, combat corruption, will enable the growth of human potential and competitiveness, as well as accelerate the decentralization process in Ukraine.

3. Modern political, socio-economic and information-communication tools of interaction between the state and society in Ukraine are constantly improving under the influence of new challenges that cause changes in public policy-making processes, which in its evolutionary development requires both rethinking traditional management approaches and applying new ones. service-oriented mechanisms for its formation and implementation.

4. The creation of digital infrastructures is a major factor in expanding citizens' access to the global information environment and knowledge [21]. Thus, serial activity - should focus on the priority of the rights and legitimate interests of individuals and citizens who are customers of public services in a service-oriented state.

5. In 2011, free access to the Internet was recognized by the UN as a fundamental human right - digital law. Thus, the need for access to information about the public service and the possibility of influence and legal support should be provided by the authorities and is the basis of public administration, which, among other things, will provide a real opportunity to counter inefficiencies in management, economic development and corruption. The interaction between public authorities and the citizen should be based on the openness and quality of services provided by the state and is impossible without appropriate technological support, which evolves from informatization to digitalization of public administration and local self-government.

\section{References}

Charter of Fundamental Rights of the European Union. International document. European Union.07.12.2000.Electronic document. Access mode: https://zakon.rada.gov.ua/laws/ show/994_524\#Text [in Ukrainian] 
United Nations study. Digital government. Decades of action for Sustainable Development. URL: $\quad$ https://publicadministration.un.org/egovkb/Portals/egovkb/Documents/un/2020-Survey/2020\%20UN\%20E-Government\%20Survey\%20(Full\%20Report).pdf [in English]

Strategy. European digital decade. International document. Brussels. 03/09/2021 URL: https:// ec.europa.eu/commission/presscorner/detail/en/IP_21_983 [in English]

Ukraine 2030e - a country with a developed digital economy.// Ukrainian Institute of the Future. URL: $\quad$ https://strategy.uifuture.org/kraina-z-rozvinutoyu-cifrovoyu-ekonomikoyu.html\#6-2-6 [in Ukrainian]

Sait informaziynich poslug. [Official site of information services] https://www.belgium.be/fr/ justice/securite

Sait informaziynich poslug. [Official site of information services] https://eng.em.dk/ media/10566/digital-growth-strategy-report_uk_web-2.pdf

Sait informaziynich poslug. [Official site of information services] https://www.service. bund.de/Content/DE/Service/Ueber-service-bundde/ueber-service-bundde_node.html\#doc4641996bodyText3

Sait informaziynich poslug. [Official site of information services] https://www.imda.gov.sg/ infocomm-media-landscape/SGDigital

Sait informaziynich poslug. [Official site of information services] https://www.state.gov/digital-government-strategy/

Sait informaziynich poslug. [Official site of information services] https://www.digitaldialog. swiss/en/

Sait informaziynich poslug. [Official site of information services] https://www.oecd-ilibrary. org/science-and-technology/oecd-reviews-of-digital-transformation-going-digital-in-sweden_9789264302259-en 